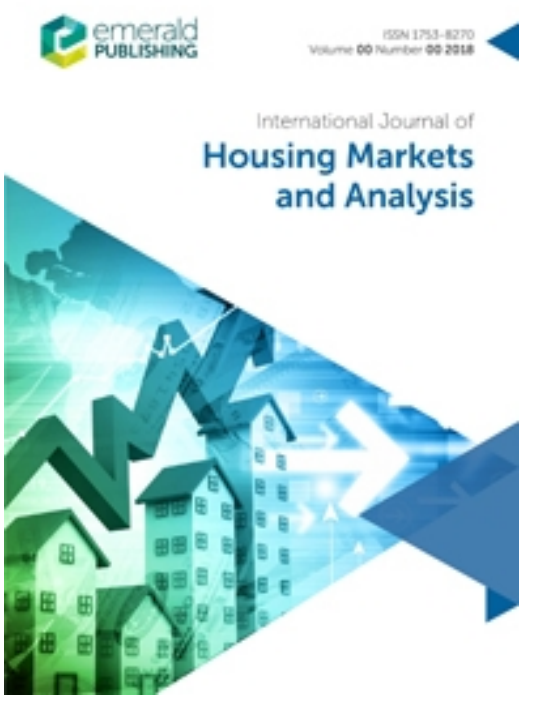

\title{
Impact of Light Rail Line on Residential Property Values - A Case of Sydney, Australia
}

\begin{tabular}{|r|l|}
\hline Journal: & International Journal of Housing Markets and Analysis \\
\hline Manuscript ID & IJHMA-03-2021-0033.R1 \\
\hline Manuscript Type: & Research Paper \\
\hline Keywords: & $\begin{array}{l}\text { Light rail, property value, university, Residential property, Sydney, } \\
\text { Australia }\end{array}$ \\
\hline
\end{tabular}

\section{SCHOLARONE ${ }^{\mathrm{m}}$ \\ Manuscripts}




\section{ABSTRACT}

7 Purpose - The construction of new transportation infrastructure tends to affect the adjoining properties, 8 economy, and environment. In particular, studies have investigated the change in the value of properties 9 due to increased access to transportation facilities. In this current study, the impact of the recently 10 completed light rail on residential property values in Sydney, Australia was examined.

11 Design/methodology/approach - Sales data of residential properties were extracted from the 12 13 14

\section{Impact of Light Rail Line on Residential Property Values - A Case of Sydney, Australia}

2 CoreLogic's RP database. The hedonic pricing model (HPM) was used to assess the effect of proximity

3 to the light rail stops. Two models were developed for the announcement and construction phases of 4 the light rail project.

Findings - It was found that during the announcement phase, properties located within the $400 \mathrm{~m}$ radius from the station were $3.3 \%$ more expensive than those within the $400-800$ radius. At the construction stage, the properties within the $0-400 \mathrm{~m}$ radius from the stops sold at $3.1 \%$ more than those within the 400-800m radius. The study concludes that a positive relationship exists between the values of residential property and its proximity to the light rail stations.

Originality -Previous studies that aimed at examining the impact of light rails on residential properties values around universities are limited. Hence, this study provides a broad perspective on the impact of light rail on residential properties values-around a university.

23 Practical implications - These findings would be useful for policymakers to develop land value 24 capture programs for infrastructure funding and to real estate professionals and investors for investment 25 in future transit-oriented development.

27 Keywords: Light rail, property value, university, residential property, Sydney, Australia 


\section{INTRODUCTION}

2

3 The urban areas within nations play a significant role in economic development. As the number

4 of people living in cities grows, the volume of carbon emissions increase (Shi, 2003; Jorgenson

$5 \&$ Clark, 2010). Research shows that congestion within cities increases the volume of 6 greenhouse emissions from fossil-powered vehicles (Zheng et al., 2015). Across the globe,

7 stakeholders are implementing strategies [such as mass transportation, emission charge, and 8 incentives to encourage the purchase of electric cars] to improve air quality and reduce 9 congestion in the cities (Steffen et al., 2015; Zheng et al., 2020). The construction of light rail 10 systems for mass transportation is beneficial to the people, community, environment, and economy. Light rail systems are vital for the growth and long-term survival of cities.

The relationship between transportation and land use is significant. A common way to measure the relationship is to examine how property values vary with distance to a transportation facility (Ryan, 1999). The findings of previous studies into the impact of railway stations on the values of residential properties have been inconsistent. For instance, some studies indicate the rail stations have no (Wagner et al., 2017) or negative impact on property values (Camins-Esakov \& Vandegrift, 2018). In contrast, other investigations suggest that the proximity to rail stations has a positive impact on property values (Hess \& Almeida, 2007; Pan et al., 2014). These inconsistencies have been attributed to (i) ownership (low and high-income) and characteristics (single-family and multi-family) of the residential properties (Duncan, 2008; Forouhar \& Hasankhani, 2018). These inconsistencies necessitate the need for fresh insights into the impact of railway stations on the values of residential properties.

An understanding of the attributes that influence property values can be used to inform investment and policy decisions. In the context of Australia, the existence of previous studies 
1 (Mulley \& Tsai, 2016; Chen et al., 2019) which focused on the impact of railway lines on the

2 value of residential properties is acknowledged. However, little is known about the impact of

3 the recently completed Central Business District (CBD) and South East (SE) light rail line on

4 the values of residential properties around a university, i.e. the University of New South Wales

5 (UNSW), Sydney, Australia. Due to the gap in the existing knowledge, this study seeks to

6 investigate how the CBD and SE Light Rail (CSELR) influence the value of residential

7 properties located around the UNSW transit stops. The aim of the study is achieved by

8 addressing two objectives: (i) to examineexamining the influence of the new light rail on

9 residential property values around UNSW during the announcement (December 2012 10 February 2015) and construction (March 2015 - March 2020) of the light rail; and (ii) to 11 assessassessing the effect of distance to the new light rail on residential property values around

12 UNSW. The outcome of the present study provides insights into the economic benefits 13 associated with the development of light railway systems within cities. This information can 14 be used by stakeholders (such as government and developers) to develop strategies for the 15 planning of land value capture for future infrastructure funding. It will also be of added value 16 to consumers in real estate markets when deciding on where and when to buy or lease 17 properties.

19 LITERATURE REVIEW

Accessibility and Nuisance Effects on Property Values

21 The findings of previous studies on the impact of transport infrastructure on the value of 22 properties have been inconsistent. Previous studies show that the closeness to a railway station 23 contributes to an increase in the value of properties (Debrezion et al., 2007; Li, 2018; Pan, 24 2019). In contrast, Wagner et al. (2017) found that the proximity to railway stations has no 25 impact, while Camins-Esakov and Vandegrift (2018) reported a negative impact on the values 
1 of properties. Literature suggests that the impact of transport infrastructure on the value of

2 residential properties tend to vary from location to location. Considering all thoise evidence, it

3 seems that the presence of railway stations could be beneficial or detrimental to the value of

4 residential properties. Furthermore, several studies have been conducted to understand the 5 underlying reasons for these inconsistencies.

6

7 Researchers have used various tools and techniques to explain theseis inconsistent finding $\underline{\underline{s}}$.

8 Most authors have incorporated spatial data into developed models. In other cases, buildings

9 have been classified based on characteristics, such as ownership. For instance, previous studies 10 have shown that the proximity of train stations to properties in low-income neighbourhoods increases their values, however, it has a negative impact in high-income areas (Nelson, 1992; Forouhar \& Hasankhani, 2018; Zhang et al., 2021). Using geospatial data, Bowes and Ihlanfeldt (2001) showed that properties located within 0.25 miles of the MARTA (Metropolitan Atlanta Rapid Transit Authority) sold for 19 per cent less than outside of the three-mile radius. The existing literature on this subject is summarised and presented in Fable 1 Appendix 1. Based on the evidence, scholars have attributed the observed inconsistencies to various reasons.

The factors suggested by scholars include the level of car ownership, noise population, and perceived level of security, among others. Forouhar and Hasankhani (2018) observed that train services tend to be utilised as the main means of transportation among low-income families. However, high-income earners can afford to own cars and pay for other associated costs, such as maintenance costs. Others (such as Bowes \& Ihlanfeldt, 2001) stated that the presence of rail stations improves access to a locality. However, the perceived level of security and noise pollution tends to adversely affect the value of residential properties. From Fable 1 Appendix 1 , 
1 there is a need to understand the impact of railway stations on the value of residential properties

2 in other cities outside of the US.

\section{Residential Property Values: Modelling and Prediction}

9 Various tools have been used to model the relationship between the value of residential 10 properties and their attributes. Research shows that these attributes contribute to the value of 11 properties (Jenkins, 2000). according to Chen et al. (1998), tThese attributes according to 12 Chen et al. (1998)-were classified into structural, neighbourhood, locational, fiscal or 13 economic attributes. In contrast, Mohammad et al. (2013) categorised these attributes into 14 internal, external, and economic (see Figure 1). The nomenclature of the property attributes 15 classifications have has not been consistent in the literature (Chin \& Chau, 2002). Taken 16 together, the literature suggests that the attributes of properties have a significant impact on 17 their value. Unearthing the relationship between attributes and property value is vital for 18 optimising the returns on investment.

\section{Insert Figure 1 Here}

25 There is a growing number of researches that models and predicts residential property values using its attributes. Information gleaned from the literature indicates that the features 27 influencing property values include the number of bedrooms, bathrooms, parking space, 28 proximity of green parks, and academic performance of students in state schools, among 


\section{Insert Table 2Table 1 Here}

27 Numerous studies have attempted to explain the impact of different levels of schools

others (Crompton, 2001; Abidoye \& Chan, 2017; Fleishman et al., 2017). Table 2Table 1 provides a concise overview of the variables incorporated into models for the prediction of property value. Lines of evidence have shown that these features are useful for modelling and predicting residential property values (Nguyen \& Cripps, 2001; Abidoye, 2017). The impact

of these attributes tends to vary from one location to another. Hence, the need to understand

6 the critical features-attributes that contributes to property values in each location.

7

(3)

(3)

\section{University Impact on Residential Property Values}

The presence of UNSW within the study area necessitates the review of studies on the effect of education facilities on the value of residential properties. Much of the research has focused on the impact of school quality, measured in terms of students' academic performance, on the value of properties. For instance, studies have shown that school quality has a positive impact on residential property values (Chin \& Foong, 2006; Wen et al., 2014). However, little is known about the effect of school proximity on property values. Hence, there is a need to understand the impact of the presence of a university on the value of residential properties, using UNSW as a representative case.

on the value of residential properties. For instance, Owusu-Edusei et al. (2007) found 
1 that elementary and high schools had a great impact on the values of residential

2 properties in South Carolina, US. Similarly, studies have reported that the presence of

3 school is a significant contributory factor to the values of residential properties in

4 South Korea, China, and the United Kingdom (Davidoff \& Leigh, 2008; Hahn et al., 5 2012; Wen et al., 2014). Wen et al. (2014) showed that the strength of this relationship

6 varies based on the class of the school, e.g. kindergarten schools, high schools, or

7 college. Collectively, it is evident that the proximity and accessibility of all schools

8 have a positive effect on the value of residential properties. These studies highlight

9 the place of educational facilities on property value formation in economic success.

\section{RESEARCH METHODOLOGY}

13 Several techniques have been used for modelling and prediction-predicting $\theta f$ 14 residential property values. The methods used in previous studies can be classified 15 into two groups: quantitative and qualitative. The main advantage of quantitative 16 methods lies in the possibility of objectively verifying and validating the developed 17 model. Despite the existence of several quantitative methods (see Table 1 Appendix 18 1), the suitability of a particular approach is dependent on the objectives of the study. 19 In this study, the HPM is used to model and explain the strength of the relationship 20 between the value of a residential property and its attributes. HPM utilises the 21 regression analysis to deconstruct the value of a residential building and estimates the 22 contributory significance of each available characteristic (Selim, 2009). Yacim and 23 Boshoff (2014) point out that the main weakness of HPM is the non-inclusion of the 24 spatial information about residential properties. A better approach would be the 25 inclusion of a dummy variable, which represents the distance between a property and 26 the railway station, in the HPM. Geographic Information System (GIS) is a useful tool 
1 for evaluating the impact of distance on the value of real estate properties (Anselin,

2 1998). For this study, the dummy variables were included in the HPM model to

3 evaluate the impact of distance to a railway station on property value.

4 The variables included in the quantitative models, i.e. HPM, were informed by the

5 outcome of an initial review of the literature. As stated earlier, dummy variables were

6 used to investigate the impact of the proximity of light rail stops on residential property

7 values. In this research, HPM was applied to data collected from two time periods (

8 (i) the announcement of the new train line and (ii) the completion of the new train

9 station). The variables included in the developed HPM are shown in Fable 3Table 2.

10 The HPM developed in this study can be specified as a multiple regression as shown in

11 Equation 1.

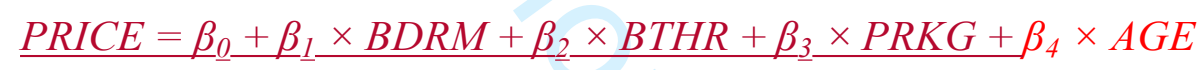$$
+\beta_{5} \times A R E A+\beta_{6} \times L O T S Z+\beta_{7} \times P T Y P E+\beta_{8} \times D 400+\beta_{9} \times D 800+\varepsilon
$$

15 Where $\beta_{0}$ is the regression constant $\beta_{1} \ldots B_{9}$ are the regression coefficients (described and 16 listed in Table 2) and $\varepsilon$ is the random error.

Insert Table 2 Here

\section{Study Area}

25 The new CSELR in Sydney, Australia comprises of the L2 (Randwick Line) and the

26 L3 (Kingsford Line). The CSELR is 12 kilometres and it has 19 stops. The 27 development phase of the CSELR project spanned between December 2012 and 
1 March 2020. The government of New South Wales declared and announced the

2 intention to procure the project in December 2012. Planning permission was granted

3 in 2014. Subsequently, the construction phase commenced in March 2015 and the

4 project was completed in early 2020 . The Randwick Line was opened and operational

5 on December 14, 2019, while the Kingsford Line continued testing through the first

6 quarter of 2020 and opened for passengers on April 3, 2020.

7 Two light rail stations served the UNSW community - one via L2 on High Street and

8 one via L3 on Anzac Parade. The impact of these two stops on the value of residential

9 properties is the main focus of the current study. The residential properties were

10 grouped into two classes, i.e. those within the $0-400 \mathrm{~m}$ radius and those located within

11 the $401-800 \mathrm{~m}$ radius. This is a common metric used in similar previous studies (see,

12 for instance, Weinberger, 2001; Hess \& Almeida, 2007; Pan, 2013). Also, Zhong and

13 Li (2016) mentioned that some residents are willing to walk about $800 \mathrm{~m}$ to a transit

14 stop in America. Figure 2 shows the location of the two rail stations in proximity to

15 the UNSW's Kensington campus.

\section{Data Collection}

26 The secondary data used for the study was retrieved from CoreLogic's RP database 27 (https://www.corelogic.com.au/). The descriptive statistics for the variables included 28 in the HPMs are presented in Table 4 Table 3 (' $\mathrm{N}$ ' indicates the number of observations 29 per model). The selection criteria for the variables are (i) the outcome of the literature 30 review (Table 2Table 1) and (ii) the availability of data on the RP database. Upon 
1 completion of data cleaning, a total of $702(286+416)$ complete observations were

2 available for the development of the quantitative models. The data was collected for

3 residential properties sold and bought within the study area between December 2012

4 and March 2020 when the new rail line was completed. To have consistent property

5 values consummated between 2012 and 2020, the effect of inflation was considered.

6 Therefore, the Consumer Price Index (CPI) retrieved from the Australian Bureau of

7 Statistics (ABS) was applied to the data. The dataset was divided into the light rail

8 announcement (T1) and construction (T2) phases. The post-construction phase was

9 not considered in the study due to the outbreak of the COVID-19 pandemic. This is

10 because global events, such as recession and pandemics, tend to disrupt the housing

11 markets (Lai et al., 2006). This disruption informed the authors' decision not to include

12 post-construction data into the developed HPM. The descriptive statistics and HPM

13 were then generated using the Statistical Package for the Social Sciences (SPSS).

14 Table 4 Table 3 is presents the descriptive statistics showing an increasing value in the 15 average sales price of residential properties when the $\mathrm{T} 1$ and $\mathrm{T} 2$ periods are compared.

21 Results and Discussion

22 The output of the developed models is summarised in Table 5Table 4. Lin and Mohan 23 (2011) posit that the closer thean $r^{2}$ value is closer to 1 demonstrates higher confidence 24 of correlation between the dependent and independent variables. The models for T1 
1 and T2 have $r^{2}$ values of .808 and .867 , and adjusted $r^{2}$ values of 0.801 and .864 ,

2 respectively. This metric indicates that the models can explain over 80 per cent 3 variance ( $80.8 \%$ for $\mathrm{T} 1$ and $86.7 \%$ for $\mathrm{T} 2$ ) in the values of residential properties. From 4 these values, both models demonstrate the goodness-of-fit of the HPM (Abidoye, 5 2017).

6 7

15 Tables $\underline{5} 6$ and $\underline{6} 7$ presents the regression results of the two models during the 16 announcement and construction phase, respectively. The results provide insight into 17 whether each independent variable is significant in contributing to property values 18 during those periods. A p-value of less than .05 means the variable is significant at the 195 per cent significance level and less than .01 means highly significant at the 1 per 20 cent significance level. The collinearity statistics column provides information on 21 whether multicollinearity is present among the variables. To test for multicollinearity, 22 as a general rule of thumb, a variance inflation factor (VIF) value of less than 10 is 23 considered acceptable (Berenson et al., 2012). The values of VIF shown in Tables $\underline{5} 6$ 24 and $\underline{6} 7$ are less than 10 . Hence, it is evident that there is no multicollinearity among 25 the variables included in the models. 
Insert Table $6 \underline{5}$ Here

Insert Table $7 \underline{6}$ Here

\section{Property Characteristics}

17 The characteristics of the properties (size of the property, number of bedrooms, 18 number of parking spaces, and property type) are significant and have a positive 19 correlation to the value of the residential properties. This finding is consistent with 20 those of previous studies which indicate that structural variables are the most 21 significant drivers of property values (Wilhelmsson, 2000; Abidoye \& Chan, 2016; 22 Chen et al., 2019). This may be because structural attributes of properties are usually 23 significant in the formation of property values (Wilhelmsson, 2000), and they could 24 contribute above 60 per cent to the formation of residential property values (Wen et 25 al., 2005).

26 The number of bathrooms was found to be significant during T1 but not significant in 27 T2. In T2 the number of bathrooms had a negative correlation to property value and 28 for every increase in the number of bathrooms, there is a 1.7 per cent decrease in 29 property value. The plausible reason might be that the home buyers were more 30 concerned about other variables than the number of bathrooms during this period to 31 secure properties close to the light rail stops. This result is similar to the findings of 32 Abidoye and Chan (2018) and Nguyen and Cripps (2001) that reported that an 
1 additional number of bathrooms could reduce the price of residential properties.

2 Property type was found to be highly significant in both T1 and T2. The positive

3 correlation indicates that the average value of standalone houses is higher than those

4 of flats/units. After all other variables are accounted for, the values of properties are

5 predicted to be 49 per cent more than the value of units in T1 and 65 per cent more in

6 T2. This corroborates Mulley and Tsai (2016) that found that units were valued lesser

7 than houses within the same property market. This result could be explained by the

8 fact that houses provide more space, privacy, and amenities when compared with units.

9 These additional features make houses command a higher value.

10

11 In model $\mathrm{T} 1$, the age of property is not significant, but in $\mathrm{T} 2$, the age of property is

12 significant at the 5 per cent significance level. One reason age is not significant in T1

13 could be that particular architectural styles of properties, such as federation style, may

14 appreciate due to historical value. On the other hand, it has been established in the

15 literature that the older a property, the lesser the value (Hui et al., 2007), and this

16 explains the negative correlation in $\mathrm{T} 2$.

17 The results for both the D400 and D800 are not significant during T1. The positive 18 coefficients of those variables can be interpreted as properties in the two zones that 19 enjoy value-added due to proximity to the stops. Properties located within the $0-400$ $20 \mathrm{~m}$ range of the stops are predicted to sell for 4.3 per cent premium, while those in the 21 401-800 $\mathrm{m}$ range sold at about 1 per cent premium. This suggests that during the 22 announcement phase, properties located in direct proximity to the planned stops did 23 not experience a negative influence on their values. This outcome is contrary to 24 previous studies (such as Chen et al., 1998; Bowes \& Ihlanfeldt, 2001; Pan, 2013) who 25 found that the railway stations had a negative effect on properties adjacent to the train 
1 stations. This outcome may be because T1 is before the construction and operation of

2 the LRT so negative externalities were not yet present. Also, residential properties

3 located within the $0-400 \mathrm{~m}$ radius of the two stops are close to the UNSW. The

4 proximity to the university could explain the high value attached to properties located

5 within the $0-400 \mathrm{~m}$ radius. Previous studies have shown that the ease to access school

6 facilities tends to have a positive influence on residential property values (Clark \&

7 Herrin, 2000; Chin \& Foong, 2006). On the other hand, this result contradicts the findings

8 of Yan et al. (2012) who reported that the positive influence is only experienced during

9 the operation of light rails. However, there may be other explanatory variables for the

10 negative impact e.g. the presence of surrounding industrial land use.

11

12

13

14

In T2, the D400 variable was highly significant at 1 per cent significance level and D800 was not significant at 1 and 5 per cent significance levels. Both variables are again positively associated as they were in T1. Properties within $0-400 \mathrm{~m}$ of the stops are expected to sell with a 6.7 per cent premium, while those within 401-800 m were expected to sell with a 3.6 per cent premium. This finding shows that properties closer to the light rail stops were valued higher than those located outside the 0-400 m radius. Since both $\mathrm{T} 1$ and $\mathrm{T} 2$ produced results that indicate higher property values closer to the LRT stops, this could mean properties directly adjacent to the stops were not affected by negative externalities. One possible reason for this could be linked to the fact that LRT technology does not produce noticeable negative externalities. The CSELR is powered by electricity and it produces less air pollution when compared with fossil powered variants. However, the overhead cables of the CSELR may affect the aesthetical views in the city. The results also suggest that the capitalisation effect of being located closer to UNSW may cancel out the negative externalities or is actually greater than that of the new transit 
system altogether.

\section{Development Timeline}

4 By comparing the results of $\mathrm{T} 1$ and $\mathrm{T} 2$, the development timeline of $\mathrm{T} 2$ appears to have a

5 higher positive effect on residential property values. This is evident as both the

6 minimum and maximum sale price of properties in T2 are higher than that of T1. Most

7 of the variables also saw an increase in their coefficient from T1 to T2. With regards

8 to distance, the coefficient for properties located within $0-400 \mathrm{~m}$ of the stops saw an

9 increase of 2.4 per cent in their values, while and properties within $400-800 \mathrm{~m}$ saw an

10 increase of 2.6 per cent in value. This can be interpreted as the impact of CSELR on

11 property values improved from the announcement phase to the construction phase.

12 The observed increase in value during the development timeline is in line with 13 previous studies such as Yan et al. (2012), Chen et al. (2019) among others. There is a possibility that the values of residential properties would still increase when the new rail line becomes operational because would-be homeowners may not be willing to invest early as benefits of the transit system such as accessibility and travel cost

17 savings cannot be actualised until the system is operational.

19 Proximity and timing are the variables of interest in this study. In terms of timing of value uplift, T2 outperformed T1. From the lens of proximity, it is evident that 21 accessibility to rail stations led to increased property values. Overall, residential 22 property values increased with proximity to LRT stops and did not appear to be affected by negative externalities. Residential property values were also positively affected during the announcement and construction phase but were only statistically significant during the construction phase. 


\section{Conclusions}

3 The impact of LRT accessibility on the value of residential properties has been

4 inconclusive in the existing literature. This present study aimed to address this gap in

5 knowledge by examining the effect of a new light rail system on residential property

6 values around UNSW in Sydney, Australia. Also, the effect of the rail system during

7 the development timeline was evaluated. Using HPM, the study was able to address

8 the objectives of the research. The results of this investigation have shown that

9 residential property values increased during the announcement and construction phase

10 of the railway project. Also, it was found that residential properties located within the

$110-400 \mathrm{~m}$ radius attract more value when compared with properties far away from the 12 railway stops.

13 The current study provides insights into the impact of railway stations on the value of

14 residential properties. Overall, evidence indicates that the proximity to railway stations

15 contributes to an increase in the value of residential properties. Apart from providing

16 jobs to the people, it is evident that new transport infrastructure, such as the LRT

17 system, can add value to the community. Based on the evidence of value uplift,

18 policymakers need to develop policies to optimise the capture of the value of 19 investments in infrastructure projects. Also, stakeholders, such as real estate 20 professionals and property investors, can use this information to objective inform 21 property investment decisions.

22 The findings emanating from the study are subject to certain limitations. First, the 23 variables included in the HPM model was not exhaustive. For instance, there was no 24 information on green features, such as gardens, within the database. Second, the 25 general state of the economy after the completion of the CSELR was not considered. 26 Due to the outbreak of COVID-19, the data for the post-construction phase is not 
1 currently available. Despite these limitations, the study contributes to the existing

2 knowledge on the impact of transport infrastructure on the value of residential

3 properties. As more data become available, further research could explore the impact

4 of CSELR on the value of properties at the post-construction phase.

\section{References}

7

8

9

10

11

12

13

14

15

16

17

18

19

20

21

22

23

24

25

26

27

28

29

30

31

32

33

34

35

36

37

38

39

40

41

42

43

44

Abidoye, R. B. (2017). Towards property valuation accuracy: A comparison of hedonic pricing model and artificial neural network. (Doctorate Degree), The Hong Kong Polytechnic University, Hong Kong. Retrieved from http://ira.lib.polyu.edu.hk/bitstream/10397/70359/2/991021965755503411 pir a.pdf (LG51 .H577P BRE 2017 Abidoye)

Abidoye, R. B., \& Chan, A. P. (2018). Hedonic valuation of real estate properties in Nigeria. Journal of African Real Estate Research, 3(1), 122-140.

Abidoye, R. B., \& Chan, A. P. C. (2016). Critical determinants of residential property value: Professionals' perspective. Journal of Facilities Management, 14(3), 283-300.

Abidoye, R. B., \& Chan, A. P. C. (2017). Critical review of hedonic pricing model application in property price appraisal: A case of Nigeria. International Journal $\begin{array}{lllll}\text { of Sustainable Built Environment, 6(1), } 250 \quad-259 . & .\end{array}$ doi:10.1016/j.ijsbe.2017.02.007

Anselin, L. (1998). GIS research infrastructure for spatial analysis of real estate markets. Journal of Housing Research, 9(1), 113-133.

Berenson, M., Levine, D., Szabat, K. A., \& Krehbiel, T. C. (2012). Basic business statistics: Concepts and applications. Australia: Pearson Higher Education AU.

Bowes, D. R., \& Ihlanfeldt, K. R. (2001). Identifying the impacts of rail transit stations on residential property values. Journal of urban Economics, 50(1), 1-25.

Camins-Esakov, J., \& Vandegrift, D. (2018). Impact of a light rail extension on residential property values. Research in Transportation Economics, 67, 11-18.

Chen, H., Rufolo, A., \& Dueker, K. J. (1998). Measuring the impact of light rail systems on single-family home values: A hedonic approach with geographic information system application. Transportation Research Record, 1617(1), 38-43.

Chen, Y., Yazdani, M., Mojtahedi, M., \& Newton, S. (2019). The impact on neighbourhood residential property valuations of a newly proposed public transport project: The Sydney Northwest Metro case study. Transportation Research Interdisciplinary Perspectives, 3, 100070.

Chin, H. C., \& Foong, K. W. (2006). Influence of school accessibility on housing values. Journal of urban planning and development, 132(3), 120-129.

Chin, T. L., \& Chau, K. W. (2002). A critical review of literature on the hedonic price model. International Journal for Housing Science and its Applications, 27(2), 145-165.

Clark, D. E., \& Herrin, W. E. (2000). The impact of public school attributes on home sale prices in California. Growth and Change, 31(3), 385-407.

Crompton, J. L. (2001). The impact of parks on property values: A review of the 
empirical evidence. Journal of leisure research, 33(1), 1-31.

Davidoff, I., \& Leigh, A. (2008). How much do public schools really cost? Estimating the relationship between house prices and school quality. Economic Record, 84(265), 193-206.

Debrezion, G., Pels, E., \& Rietveld, P. (2007). The impact of railway stations on residential and commercial property value: A meta-analysis. The Journal of Real Estate Finance and Economics, 35(2), 161-180.

Duncan, M. (2008). Comparing rail transit capitalization benefits for single-family and condominium units in San Diego, California. Transportation Research Record, 2067(1), 120-130.

Fleishman, L., Fogel, N., Fridman, I., \& Shif, Y. (2017). The effect of school performance on property values: a literature review and a case study. Journal of European Real Estate Research, 10(3), 277-302.

Forouhar, A., \& Hasankhani, M. (2018). The effect of Tehran metro rail system on residential property values: A comparative analysis between high-income and low-income neighbourhoods. Urban studies, 55(16), 3503-3524.

Hahn, S., Kim, T.-H., \& Kim, M. (2012). The influence of school quality on housing prices in Korea. Applied Economics, 44(8), 1021-1023.

Hess, D. B., \& Almeida, T. M. (2007). Impact of proximity to light rail rapid transit on station-area property values in Buffalo, New York. Urban studies, 44(5-6), 1041-1068.

Hui, E. C., Chau, C., Pun, L., \& Law, M. (2007). Measuring the neighboring and environmental effects on residential property value: Using spatial weighting matrix. Building and Environment, 42(6), 2333-2343.

Jenkins, D. (2000). Residential valuation theory and practice. Oxford: Chandos Publishing.

Jorgenson, A. K., \& Clark, B. (2010). Assessing the temporal stability of the population/environment relationship in comparative perspective: A crossnational panel study of carbon dioxide emissions, 1960-2005. Population and Environment, 32(1), 27-41.

$\mathrm{Li}$, Z. (2018). The impact of metro accessibility on residential property values: An empirical analysis. Research in Transportation Economics, 70, 52-56.

Lin, C. C., \& Mohan, S. B. (2011). Effectiveness comparison of the residential property mass appraisal methodologies in the USA. International Journal of Housing Markets and Analysis, 4(3), 224-243.

Mohammad, S. I., Graham, D. J., Melo, P. C., \& Anderson, R. J. (2013). A metaanalysis of the impact of rail projects on land and property values. Transportation Research Part A: Policy and Practice, 50, 158-170.

Mulley, C., \& Tsai, C.-H. P. (2016). When and how much does new transport infrastructure add to property values? Evidence from the bus rapid transit system in Sydney, Australia. Transport Policy, 51, 15-23.

Nelson, A. C. (1992). Effects of elevated heavy-rail transit stations on house prices with respect to neighborhood income. Transportation Research Record(1359), 127-132.

Nguyen, N., \& Cripps, A. (2001). Predicting housing value: A comparison of multiple regression analysis and artificial neural networks. Journal of Real Estate Research, 22(3), 313-336.

Owusu-Edusei, K., Espey, M., \& Lin, H. (2007). Does close count? School proximity, school quality, and residential property values. Journal of Agricultural and Applied Economics, 39(1), 211-221. 
Pan, Q. (2013). The impacts of an urban light rail system on residential property values: A case study of the Houston METRORail transit line. Transportation Planning and Technology, 36(2), 145-169.

Pan, Q. (2019). The impacts of light rail on residential property values in a non-zoning city: A new test on the Houston METRORail transit line. Journal of Transport and Land Use, 12(1), 241-264.

Pan, Q., Pan, H., Zhang, M., \& Zhong, B. (2014). Effects of rail transit on residential property values: Comparison study on the rail transit lines in Houston, Texas, and Shanghai, China. Transportation Research Record, 2453(1), 118-127.

Ryan, S. (1999). Property values and transportation facilities: Finding the transportation-land use connection. Journal of planning literature, 13(4), 412427.

Selim, H. (2009). Determinants of house prices in Turkey: Hedonic regression versus artificial neural network. Expert Systems with Applications, 36(2), 2843-2852.

Shi, A. (2003). The impact of population pressure on global carbon dioxide emissions, 1975-1996: Evidence from pooled cross-country data. Ecological economics, 44(1), 29-42.

Steffen, W., Percival, T., \& Flannery, D. (2015). Greenhouse gas emission reductions from Canberra's light rail project. Australian Planner, 52(4), 337-345.

Wagner, G. A., Komarek, T., \& Martin, J. (2017). Is the light rail "Tide" lifting property values? Evidence from Hampton Roads, VA. Regional Science and Urban Economics, 65, 25-37.

Weinberger, R. R. (2001). Light rail proximity: Benefit or detriment in the case of Santa Clara County, California? Transportation Research Record, 1747(1), 104-113.

Wen, H.-Z., Jia, S.-H., \& Guo, X.-Y. (2005). Hedonic price analysis of urban housing: An empirical research on Hangzhou, China. Journal of Zhejiang University Science, 6A(8), 907-914.

Wen, H., Zhang, Y., \& Zhang, L. (2014). Do educational facilities affect housing price? An empirical study in Hangzhou, China. Habitat International, 42, 155-163.

Wilhelmsson, M. (2000). The impact of traffic noise on the values of single-family houses. Journal of Environmental Planning and Management, 43(6), 799-815.

Yacim, J. A., \& Boshoff, D. G. (2014, 15-19 December). Mass appraisal of properties. Paper presented at the 2nd Virtual Multidisciplinary Conference, Zilina, Slovakia.

Yan, S., Delmelle, E., \& Duncan, M. (2012). The impact of a new light rail system on single-family property values in Charlotte, North Carolina. Journal of Transport and Land Use, 5(2), 60-67.

Zhang, B., Li, W., Lownes, N., \& Zhang, C. (2021). Estimating the impacts of proximity to public transportation on residential property values: An empirical analysis for Hartford and Stamford areas, Connecticut. ISPRS International Journal of GeoInformation, 10(2), 44. doi:https://doi.org/10.3390/ijgi10020044

Zheng, J., Sun, X., Jia, L., \& Zhou, Y. (2020). Electric passenger vehicles sales and carbon dioxide emission reduction potential in China's leading markets. Journal of Cleaner Production, 243, 118607.

Zheng, X., Wu, Y., Jiang, J., Zhang, S., Liu, H., Song, S., et al. (2015). Characteristics of on-road diesel vehicles: Black carbon emissions in Chinese cities based on portable emissions measurement. Environmental science \& technology, 49(22), 13492-13500.

Zhong, H., \& Li, W. (2016). Rail transit investment and property values: An old tale retold. Transport Policy, 51, 33-48. 


\section{Table 1: Variables Used in Previous Studies}

\section{Authors}

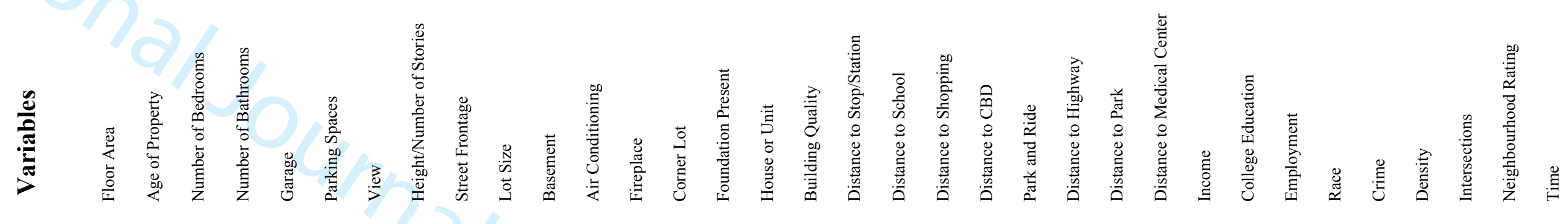

AlQuhtani and Anjomani

Chen et al. (2019)

Hopkins (2018)

Mulley et al. (2018)

Li (2018)

Mulley and Tsai (2016)

Wang (2016)

Xu et al. (2016)

Zhong and Li (2016)

Pan (2013)

Ibeas et al. (2012)

Yan et al. (2012)

Andersson et al. (2010)

Duncan (2008)

Hess and Almeida (2007)

Bowes and Ihlanfeldt (2001)

Chen et al. (1998)

Nelson (1992) TOTAL

$$
\begin{array}{lllll}
X & X & X & X & X \\
X & X & X & X & \\
& & X & X & X
\end{array}
$$

$$
\begin{array}{llll}
X & X \quad X \quad X
\end{array}
$$

$$
\text { X X }
$$

$$
\text { X X }
$$

$\begin{array}{llll}\mathrm{X} & \mathrm{X} & \mathrm{X} & \mathrm{X}\end{array}$

$$
\begin{array}{ll}
X & X \\
X & X
\end{array}
$$

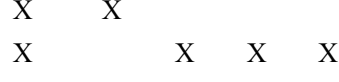$$
\mathrm{X} \quad \mathrm{X} \quad \mathrm{X}
$$$$
\mathrm{X} \quad \mathrm{X}
$$$$
\begin{array}{lllll}
x & X & X & X & X
\end{array}
$$$$
\mathrm{X}
$$
X

$$
\begin{array}{lllllllll}
X & X & X & X & X & x & & X \\
& x & x & x & & & &
\end{array}
$$$$
\mathrm{X} \quad \mathrm{X} \quad \mathrm{X}
$$$$
\mathrm{X} \quad \mathrm{X}
$$$$
\begin{array}{cccc}
X & X & X & \\
X & X & X & X
\end{array}
$$$$
\begin{array}{lllllll}
x & x & x & x & x & x & x
\end{array}
$$$$
\begin{array}{lllrr}
X & & & X & \\
12 & 12 & 12 & 12 & 3 \\
\hline
\end{array}
$$

$\mathrm{X} \quad \mathrm{X} \quad \mathrm{X}$

$\mathrm{X} \quad \mathrm{X} \quad \mathrm{X}$

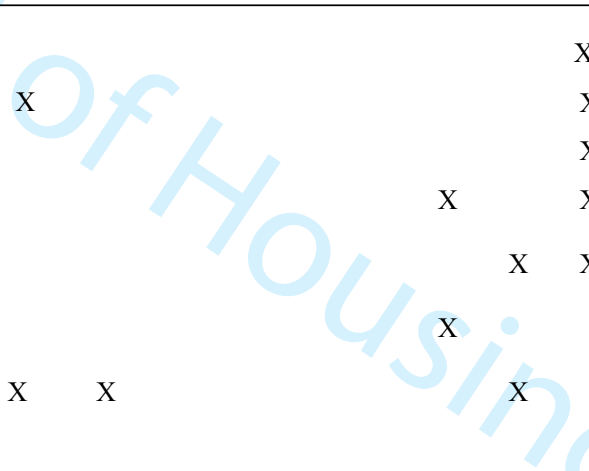

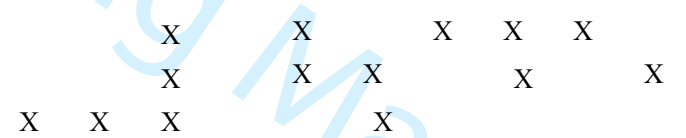

$\mathrm{X}$

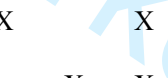

$\mathrm{X}$

X $\quad \mathrm{X}$

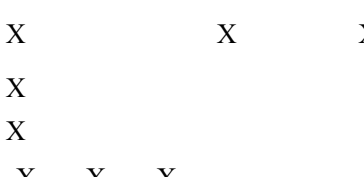

$x$

\begin{abstract}
$\begin{array}{llll}X & \mathrm{X} & \mathrm{X} & \mathrm{X}\end{array}$
\end{abstract}
$\begin{array}{lllll}X & X & X & X & X\end{array}$

$\begin{array}{lll}x & x & x\end{array}$

$\begin{array}{ll}X & X \\ X & X\end{array}$

$\mathrm{X}$ 
Table 2: Summary of Variables

\begin{tabular}{ll}
\hline Variable code & Definition/Measurement \\
\hline $\begin{array}{l}\text { Dependent variable } \\
\text { PRICE }\end{array}$ & Price of property in AUD* \\
Independent variables & Number of bedrooms \\
BDRM & Number of bathrooms \\
BTHR & Number of parking spaces \\
PRKG & Age of property in years \\
AGE & Area of property in meters squared \\
AREA & Area of lot size in meters squared \\
LOTSZ & Property type where $0=$ Unit and House $=1$ \\
PTYPE & Dummy: $1=$ Property is located in $0-400 \mathrm{~m}$ to the stops and $0=$ Property is located in \\
D400 & $401-800 \mathrm{~m}$ to the stops \\
& Dummy: $1=$ Property is located in $401-800 \mathrm{~m}$ to the stops and $0=$ Property is located in \\
D800 & $0-400 \mathrm{~m}$ to the stops \\
\hline
\end{tabular}

Table 3: Descriptive Statistics

\begin{tabular}{llccccc}
\hline Model & Variable & $\mathbf{N}$ & Minimum & Maximum & Mean & Std. Deviation \\
\hline T1 & PRICE & 286 & $\$ 315,000$ & $\$ 2,850,000$ & $\$ 972,659.35$ & $\$ 529,787.02$ \\
& AGE & 286 & 1 & 114 & 46.9 & 33.993 \\
& AREA & 286 & 24 & 389 & 112.92 & 72.629 \\
& BDRM & 286 & 0 & 9 & 2.46 & 1.153 \\
& BTHR & 286 & 1 & 5 & 1.53 & 0.738 \\
PRKG & 286 & 0 & 5 & 1.28 & 0.738 \\
LOT_SZ & 286 & 100 & 6975 & 858.18 & 890.464 \\
& P_TYPE & 286 & 0 & 1 & 0.26 & 0.437 \\
& D400 & 286 & 0 & 1 & 0.15 & 0.291 \\
D800 & 286 & 0 & 1 & 0.37 & 0.488 \\
\hline T2 & PRICE & 416 & $\$ 388,000$ & $\$ 3,850,000$ & $\$ 1,428,598.57$ & $\$ 721,879.82$ \\
& AGE & 416 & 1 & 119 & 53.97 & 36.769 \\
AREA & 416 & 24 & 351 & 116.43 & 61.049 \\
BDRM & 416 & 0 & 11 & 2.73 & 1.312 \\
BTHR & 416 & 1 & 6 & 1.58 & 0.777 \\
PRKG & 416 & 0 & 5 & 1.24 & 0.729 \\
LOT_SZ & 416 & 100 & 6975 & 599.79 & 690.258 \\
P_TYPE & 416 & 0 & 1 & 0.35 & 0.479 \\
D400 & 416 & 0 & 1 & 0.11 & 0.285 \\
D800 & 416 & 0 & 1 & 0.42 & 0.483 \\
\hline
\end{tabular}


Table 4: The outputs of the two models

\begin{tabular}{ccccc}
\hline Model & R & R Square & Adjusted R Square & Std. Error of the Estimate \\
\hline T1 & 0.899 & 0.808 & 0.801 & $\$ 236,520.07$ \\
T2 & 0.931 & 0.867 & 0.864 & $\$ 266,473.39$ \\
\hline
\end{tabular}

Table 5: Regression Results of T1 (Announcement Phase)

\begin{tabular}{lllllll}
\hline & Unstandardized & & Standardized & & \multicolumn{2}{c}{ Collinearity Statistics } \\
\cline { 6 - 7 } Variable & Coefficient & Std. Error & Coefficient & P-Value & Tolerance & VIF \\
\hline (Constant) & 299072.615 & 62114.426 & & 0.000 & & \\
AGE & -2.737 & 609.503 & 0.000 & 0.996 & 0.457 & 2.187 \\
AREA & 1665.921 & 342.579 & 0.228 & $0.000^{* * *}$ & 0.317 & 3.154 \\
BDRM & 69979.407 & 21476.228 & 0.152 & $0.001^{* * *}$ & 0.32 & 3.125 \\
BTHR & 73740.179 & 30429.466 & 0.103 & $0.016^{* *}$ & 0.389 & 2.568 \\
PRKG & 54604.633 & 21856.738 & 0.076 & $0.013^{* *}$ & 0.755 & 1.325 \\
LOT_SZ & -0.535 & 16.841 & -0.001 & 0.975 & 0.873 & 1.146 \\
P_TYPE & 598145.437 & 60749.289 & 0.493 & $0.000^{* * *}$ & 0.279 & 3.587 \\
D400 & 64979.197 & 45392.838 & 0.043 & 0.153 & 0.773 & 1.294 \\
D800 & 22742.752 & 67041.932 & 0.010 & 0.735 & 0.824 & 1.214 \\
\hline
\end{tabular}

* Significant at $\mathrm{p}<0.10,{ }^{* *}$ Significant at $\mathrm{p}<0.05, * * *$ Significant at $\mathrm{p}<0.001$

Announcement phase is December 2012 - February 2015.

Table 6: Regression Results of T2 (Construction Phase)

\begin{tabular}{|c|c|c|c|c|c|c|}
\hline \multirow[b]{2}{*}{ Variable } & \multicolumn{2}{|l|}{ Unstandardized } & \multirow{2}{*}{$\begin{array}{l}\text { Standardized } \\
\text { Coefficient }\end{array}$} & \multirow[b]{2}{*}{ P-Value } & \multicolumn{2}{|c|}{ Collinearity Statistics } \\
\hline & Coefficient & Std. Error & & & Tolerance & VIF \\
\hline (Constant) & 538918.940 & 55750.664 & & 0.000 & & \\
\hline AGE & -1489.234 & 607.064 & -0.076 & $0.015^{* *}$ & 0.352 & 2.842 \\
\hline AREA & 2816.495 & 394.776 & 0.238 & $0.000 * * *$ & 0.302 & 3.313 \\
\hline BDRM & 82793.058 & 19860.177 & 0.150 & $0.000 * * *$ & 0.258 & 3.87 \\
\hline BTHR & -15883.716 & 26759.403 & -0.017 & 0.553 & 0.405 & 2.467 \\
\hline PRKG & 103929.702 & 20881.198 & 0.105 & $0.000 * * *$ & 0.756 & 1.322 \\
\hline LOT_SZ & -19.360 & 20.237 & -0.019 & 0.339 & 0.899 & 1.113 \\
\hline P_TYPE & 981064.700 & 51472.085 & 0.651 & $0.000 * * *$ & 0.288 & 3.467 \\
\hline $\mathrm{D} 400$ & 154805.107 & 48003.912 & 0.067 & $0.001 * * *$ & 0.77 & 1.298 \\
\hline D800 & 120083.533 & 65190.065 & 0.036 & $0.066^{*}$ & 0.879 & 1.138 \\
\hline
\end{tabular}

* Significant at $\mathrm{p}<0.10, * *$ Significant at $\mathrm{p}<0.05, * * *$ Significant at $\mathrm{p}<0.001$

Construction phase is March 2015 - March 2020. 


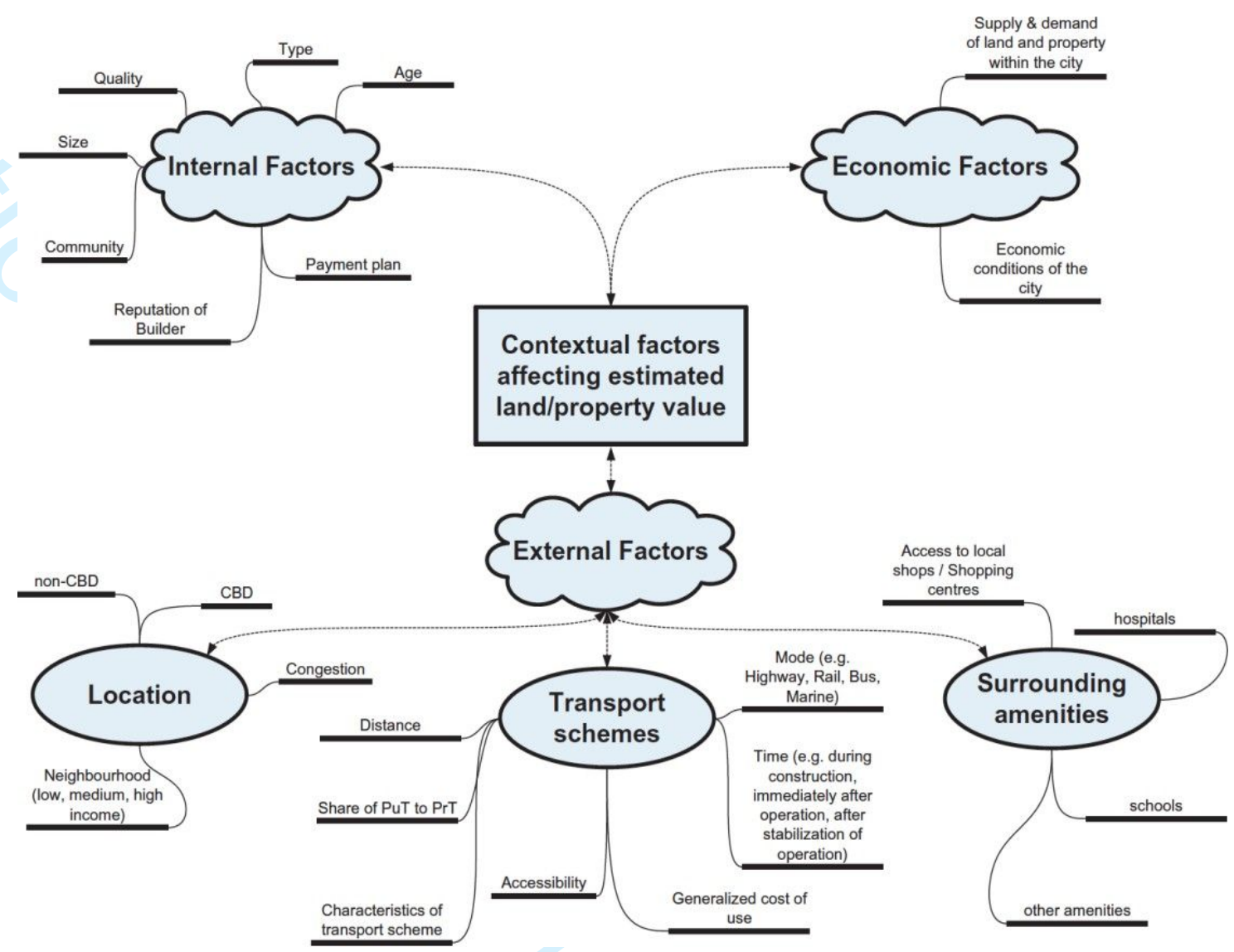

Figure 1: Factors Affecting Land/Property Values

Source: Mohammad et al. (2013)

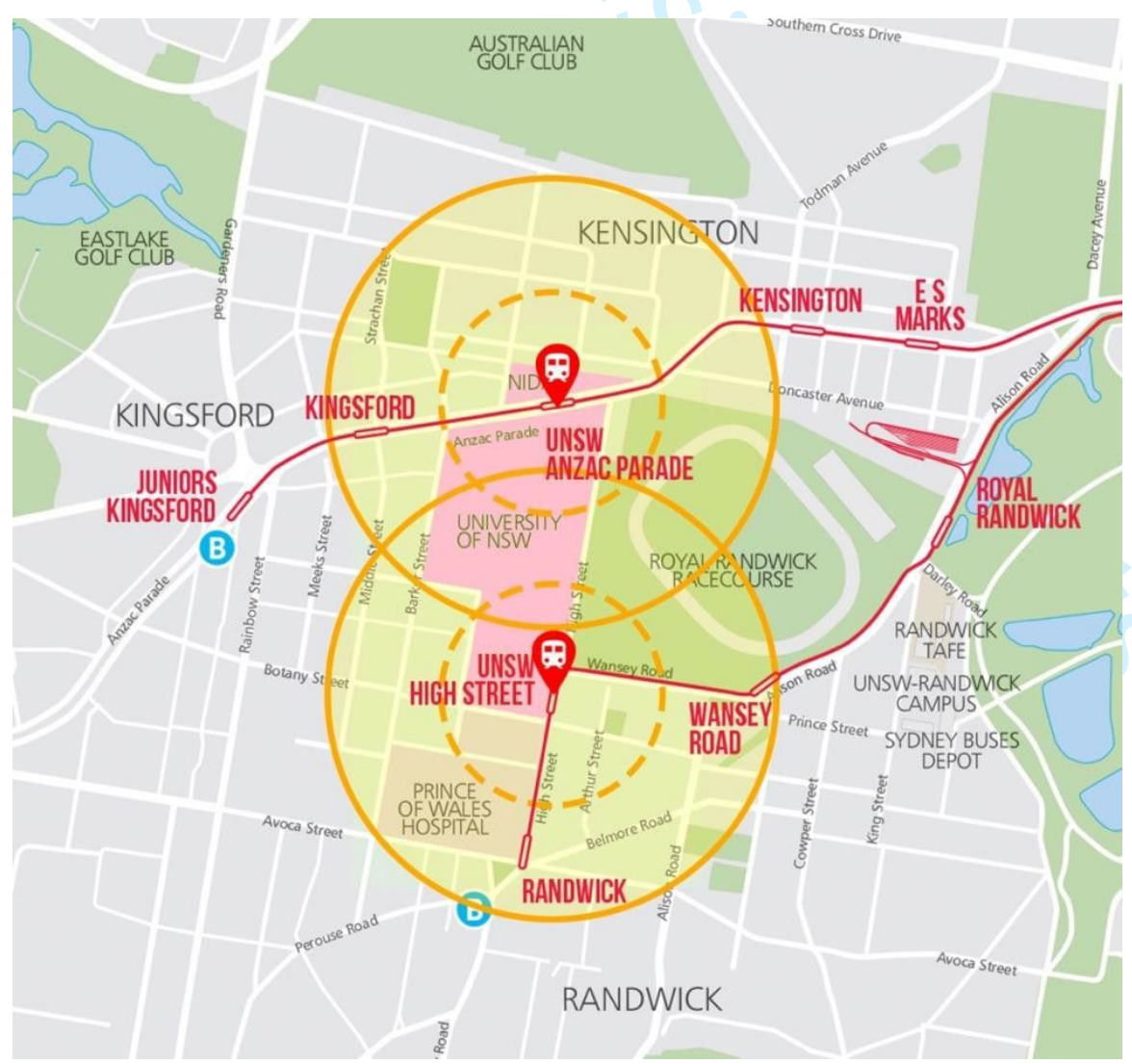

Figure 2: Map of Scope of Study

Source: https://transportnsw.info/ 


\begin{tabular}{|c|c|c|c|c|c|}
\hline Authors & Location & Transit Type & Property Type & Method & Findings \\
\hline Nelson (1992) & Atlanta, USA & Rail Transit & Single-Family & $\begin{array}{l}\text { Empirical Model, } \\
\text { Regression }\end{array}$ & $\begin{array}{l}\text { Housing values increased in low-income areas but were negatively affected in } \\
\text { higher-income neighbourhoods. }\end{array}$ \\
\hline Chen et al. (1998) & $\begin{array}{l}\text { Portland, } \\
\text { USA }\end{array}$ & Light Rail & Single-Family & $\begin{array}{l}\text { Hedonic Price } \\
\text { Model }\end{array}$ & $\begin{array}{l}\text { Housing values are impacted both negatively and positively, but the } \\
\text { positive outweighs the negative }\end{array}$ \\
\hline $\begin{array}{l}\text { Bowes and Ihlanfeldt } \\
(2001)\end{array}$ & Atlanta, USA & Rail Transit & Single-Family & $\begin{array}{l}\text { Hedonic Price } \\
\text { Model }\end{array}$ & $\begin{array}{l}\text { Homes located in direct vicinity to stations were negatively affected and those } \\
\text { located at an intermediate distance were positively affected }\end{array}$ \\
\hline $\begin{array}{l}\text { Debrezion et al. } \\
\text { (2007) }\end{array}$ & $\begin{array}{l}\text { Multiple } \\
\text { Locations }\end{array}$ & Rail Transit & Residential & Meta-Analysis & $\begin{array}{l}\text { Positive impact on property values. Commercial values benefited more at } 1 / 4 \text { or } \\
\text { less to the station than residential values. }\end{array}$ \\
\hline $\begin{array}{l}\text { Hess and Almeida } \\
(2007)\end{array}$ & $\begin{array}{l}\text { Buffalo, } \\
\text { USA }\end{array}$ & Light Rail & Single-Family & $\begin{array}{l}\text { Hedonic Price } \\
\text { Model }\end{array}$ & $\begin{array}{l}\text { Housing premium existed within a } 1 / 4 \text { mile radius of a light rail station. Actual } \\
\text { walking distance was statistically more significant than straight-line distance. }\end{array}$ \\
\hline Duncan (2008) & $\begin{array}{l}\text { San Diego, } \\
\text { USA }\end{array}$ & Rail Transit & $\begin{array}{l}\text { Single Family and } \\
\text { Condominiums }\end{array}$ & $\begin{array}{l}\text { Hedonic Price } \\
\text { Model }\end{array}$ & $\begin{array}{l}\text { The study observed a positive capitalization effect on both condominiums and } \\
\text { single-family homes. The effect was higher on condominiums. }\end{array}$ \\
\hline $\begin{array}{l}\text { Andersson et al. } \\
\text { (2010) }\end{array}$ & Taiwan & $\begin{array}{l}\text { High-Speed Rail } \\
\text { Line (HSR) }\end{array}$ & Multi-Family & $\begin{array}{l}\text { Hedonic Price } \\
\text { Model }\end{array}$ & $\begin{array}{l}\text { HSR had a very minor effect on the residential property due to the infeasibility of } \\
\text { HSR use for daily commuting. }\end{array}$ \\
\hline Campbell (2011) & $\begin{array}{l}\text { Houston, } \\
\text { USA }\end{array}$ & Light Rail & Residential & $\begin{array}{l}\text { Hedonic Price } \\
\text { Model }\end{array}$ & $\begin{array}{l}\text { Residential properties in the study were affected by both the nuisance effect } \\
\text { and accessibility effect. }\end{array}$ \\
\hline Ibeas et al. (2012) & $\begin{array}{l}\text { Santander, } \\
\text { Spain }\end{array}$ & Bus, Train & Residential & $\begin{array}{l}\text { Hedonic Price } \\
\text { Model (SEM) }\end{array}$ & $\begin{array}{l}\text { Property asking prices increased when there were more train lines present in the } \\
\text { area and decreased when distance in terms of time increased. }\end{array}$ \\
\hline Yan et al. (2012) & $\begin{array}{l}\text { Charlotte, } \\
\text { USA }\end{array}$ & Light Rail & Single-Family & $\begin{array}{l}\text { Hedonic Price } \\
\text { Model }\end{array}$ & $\begin{array}{l}\text { The study revealed a preference to live next to an Light Rail Transit (LRT) } \\
\text { station improve once the line became operational }\end{array}$ \\
\hline
\end{tabular}




\section{Appendix 1: Summary of Previous Studies (Cont.)}

\begin{tabular}{|c|c|c|c|c|c|}
\hline Authors & Location & Transit Type & Property Type & Method & Findings \\
\hline $\begin{array}{l}\text { Mohammad et al. } \\
\text { (2013) }\end{array}$ & $\begin{array}{l}\text { Multiple } \\
\text { Locations }\end{array}$ & Rail Transit & Land/Property & Meta-Analysis & $\begin{array}{l}\text { Results show large variation among studies and researchers report both } \\
\text { negative and positive impacts on land and property values. }\end{array}$ \\
\hline Pan (2013) & Houston, USA & Light Rail & $\begin{array}{l}\text { Single Family } \\
\text { Homes }\end{array}$ & $\begin{array}{l}\text { Hedonic Price } \\
\text { Model, OLS, } \\
\text { MLR }\end{array}$ & $\begin{array}{l}\text { The light rail had an overall positive effect, but properties within } 1 / 4 \text { mile } \\
\text { distance still experienced negative effects. }\end{array}$ \\
\hline $\begin{array}{l}\text { Mulley and Tsai } \\
(2016)\end{array}$ & $\begin{array}{l}\text { Sydney, } \\
\text { Australia }\end{array}$ & $\begin{array}{l}\text { Bus Rapid Transit } \\
\text { (BRT) }\end{array}$ & $\begin{array}{l}\text { Single Family and } \\
\text { Multi-family }\end{array}$ & $\begin{array}{l}\text { Hedonic Price } \\
\text { Model } \\
\text { (Multilevel) }\end{array}$ & $\begin{array}{l}\text { After the opening of the BRT, properties within } 400 \mathrm{~m} \text { of BRT stops were found to } \\
\text { have a minor positive capitalisation effect than those outside the service area. }\end{array}$ \\
\hline Wang (2016) & Seattle, USA & Light Rail & Single-Family & $\begin{array}{l}\text { Hedonic Price } \\
\text { Model }\end{array}$ & $\begin{array}{l}\text { The LRT had a statistically significant positive effect on property values after } \\
\text { construction, but not during or before construction. }\end{array}$ \\
\hline $\begin{array}{l}\text { Zhong and } \mathrm{Li} \\
(2016)\end{array}$ & $\begin{array}{l}\text { Los Angeles, } \\
\text { USA }\end{array}$ & $\begin{array}{l}\text { Heavy Rail/Light } \\
\text { Rail }\end{array}$ & $\begin{array}{l}\text { Single Family and } \\
\text { Multi-family }\end{array}$ & $\begin{array}{l}\text { Hedonic Price } \\
\text { Model, GWR }\end{array}$ & $\begin{array}{l}\text { The study saw a positive impact on multi-family residential, but single-family } \\
\text { homes were negatively impacted. Residents favour heavy rail over light rail. }\end{array}$ \\
\hline $\begin{array}{l}\text { Forouhar and } \\
\text { Hasankhani } \\
(2018)\end{array}$ & Tehran, Iran & Rail Transit & Apartments/flats & $\begin{array}{l}\text { Trend Analysis, } \\
\text { Difference in } \\
\text { Differences }\end{array}$ & $\begin{array}{l}\text { A large increase in housing premium in neighbourhoods with low income but } \\
\text { had a negative impact on neighbourhoods with a higher income. }\end{array}$ \\
\hline $\operatorname{Li}(2018)$ & China & Rail Transit & Apartments & $\begin{array}{l}\text { Empirical } \\
\text { Analysis }\end{array}$ & $\begin{array}{l}\text { Overall positive impact on property values. Value uplift is highest between } 300 \mathrm{~m} \\
\text { to } 1200 \mathrm{~m} \text { away from a station. }\end{array}$ \\
\hline $\begin{array}{l}\text { Camins-Esakov } \\
\text { and Vandegrift } \\
(2018)\end{array}$ & Bayonne, USA & $\begin{array}{l}\text { Light Rail } \\
\text { Extension }\end{array}$ & $\begin{array}{l}\text { Single Family and } \\
\text { Multi-family }\end{array}$ & $\begin{array}{l}\text { Hedonic Price } \\
\text { Model, Repeat } \\
\text { Sales }\end{array}$ & No significant impact observed \\
\hline $\begin{array}{l}\text { Mulley et al. } \\
(2018)\end{array}$ & $\begin{array}{l}\text { Sydney, } \\
\text { Australia }\end{array}$ & Light Rail & $\begin{array}{l}\text { Single Family and } \\
\text { Apartments }\end{array}$ & GWR & $\begin{array}{l}\text { Property values increase } 1 / 2 \text { per cent for each } 100 \mathrm{~m} \text { nearer to an LRT station, but } \\
\text { value uplift decreases within } 100 \mathrm{~m} \text { of a station. }\end{array}$ \\
\hline $\begin{array}{l}\text { AlQuhtani and } \\
\text { Anjomani (2019) }\end{array}$ & Dallas, USA & $\begin{array}{l}\text { Light Rail, } \\
\text { Commuter Rail }\end{array}$ & Single-Family & $\begin{array}{l}\text { Multiple } \\
\text { Regression }\end{array}$ & $\begin{array}{l}\text { Premium decreased where properties were located closer to the station. Areas } \\
\text { with development and commercial activity had the strongest positive impact on } \\
\text { housing values. }\end{array}$ \\
\hline Chen et al. (2019) & $\begin{array}{l}\text { Sydney, } \\
\text { Australia }\end{array}$ & Metro Rail & Residential & $\begin{array}{l}\text { Hedonic Price } \\
\text { Model }\end{array}$ & $\begin{array}{l}\text { The new metro rail had a negative effect on property prices during pre- } \\
\text { construction and a positive effect during construction. }\end{array}$ \\
\hline $\begin{array}{l}\text { Zhang and Jiao } \\
\text { (2019) }\end{array}$ & $\begin{array}{l}\text { Zhengzhou, } \\
\text { China }\end{array}$ & $\begin{array}{l}\text { Urban Rail } \\
\text { Transit (URT) }\end{array}$ & $\begin{array}{l}\text { Gated Residential } \\
\text { Apartments }\end{array}$ & $\begin{array}{l}\text { Hedonic Price } \\
\text { Model }\end{array}$ & $\begin{array}{l}\text { The URT had a significant higher influencing strength during its early stages } \\
\text { of planning and construction when compared with the operation periods }\end{array}$ \\
\hline
\end{tabular}




\section{ABSTRACT}

7 Purpose - The construction of new transportation infrastructure tends to affect the adjoining properties, 8 economy, and environment. In particular, studies have investigated the change in the value of properties 9 due to increased access to transportation facilities. In this current study, the impact of the recently 10 completed light rail on residential property values in Sydney, Australia was examined.

11 Design/methodology/approach - Sales data of residential properties were extracted from the 12 CoreLogic's RP database. The hedonic pricing model (HPM) was used to assess the effect of proximity 13 to the light rail stops. Two models were developed for the announcement and construction phases of 14 the light rail project.

15 Findings - It was found that during the announcement phase, properties located within the $400 \mathrm{~m}$ radius 16 from the station were 3.3\% more expensive than those within the $400-800$ radius. At the construction 17 stage, the properties within the $0-400 \mathrm{~m}$ radius from the stops sold at $3.1 \%$ more than those within the $18400-800 \mathrm{~m}$ radius. The study concludes that a positive relationship exists between the values of 19 residential property and its proximity to the light rail stations.

Originality -Previous studies that aimed at examining the impact of light rails on residential properties values around universities are limited. Hence, this study provides a broad perspective on the impact of light rail on residential properties values.

Practical implications - These findings would be useful for policymakers to develop land value capture programs for infrastructure funding and to real estate professionals and investors for investment in futuretransit-oriented development.

Keywords: Light rail, property value, university, residential property, Sydney, Australia

Paper type Research paper 


\section{INTRODUCTION}

2

3 The urban areas within nations play a significant role in economic development. As the number

4 of people living in cities grows, the volume of carbon emissions increase (Shi, 2003; Jorgenson

$5 \&$ Clark, 2010). Research shows that congestion within cities increases the volume of 6 greenhouse emissions from fossil-powered vehicles (Zheng et al., 2015). Across the globe,

7 stakeholders are implementing strategies [such as mass transportation, emission charge, and

8 incentives to encourage the purchase of electric cars] to improve air quality and reduce 9 congestion in the cities (Steffen et al., 2015; Zheng et al., 2020). The construction of light rail 10 systems for mass transportation is beneficial to the people, community, environment, and 11 economy. Light rail systems are vital for the growth and long-term survival of cities.

The relationship between transportation and land use is significant. A common way to measure

14 the relationship is to examine how property values vary with distance to a transportation facility 15 (Ryan, 1999). The findings of previous studies into the impact of railway stations on the values of residential properties have been inconsistent. For instance, some studies indicate the rail 17 stations have no (Wagner et al., 2017) or negative impact on property values (Camins-Esakov \& Vandegrift, 2018). In contrast, other investigations suggest that the proximity to rail stations 19 has a positive impact on property values (Hess \& Almeida, 2007; Pan et al., 2014). These 20 inconsistencies have been attributed to (i) ownership (low and high-income) and characteristics 21 (single-family and multi-family) of the residential properties (Duncan, 2008; Forouhar \& Hasankhani, 2018). These inconsistencies necessitate the need for fresh insights into the impact of railway stations on the values of residential properties.

An understanding of the attributes that influence property values can be used to inform investment and policy decisions. In the context of Australia, the existence of previous studies 
1 (Mulley \& Tsai, 2016; Chen et al., 2019) which focused on the impact of railway lines on the

2 value of residential properties is acknowledged. However, little is known about the impact of

3 the recently completed Central Business District (CBD) and South East (SE) light rail line on

4 the values of residential properties around a university, i.e. the University of New South Wales

5 (UNSW), Sydney, Australia. Due to the gap in the existing knowledge, this study seeks to

6 investigate how the CBD and SE Light Rail (CSELR) influence the value of residential

7 properties located around the UNSW transit stops. The aim of the study is achieved by

8 addressing two objectives: (i) examining the influence of the new light rail on residential

9 property values around UNSW during the announcement (December 2012 - February 2015)

10 and construction (March 2015 - March 2020) of the light rail; and (ii) assessing the effect of

11 distance to the new light rail on residential property values around UNSW. The outcome of

12 the present study provides insights into the economic benefits associated with the development

13 of light railway systems within cities. This information can be used by stakeholders (such as

14 government and developers) to develop strategies for the planning of land value capture for

15 future infrastructure funding. It will also be of added value to consumers in real estate markets

16 when deciding on where and when to buy or lease properties.

\section{LITERATURE REVIEW}

\section{Accessibility and Nuisance Effects on Property Values}

20 The findings of previous studies on the impact of transport infrastructure on the value of

21 properties have been inconsistent. Previous studies show that the closeness to a railway station

22 contributes to an increase in the value of properties (Debrezion et al., 2007; Li, 2018; Pan, 23 2019). In contrast, Wagner et al. (2017) found that the proximity to railway stations has no 24 impact, while Camins-Esakov and Vandegrift (2018) reported a negative impact on the values 25 of properties. Literature suggests that the impact of transport infrastructure on the value of 
1 residential properties tend to vary from location to location. Considering all those evidence, it

2 seems that the presence of railway stations could be beneficial or detrimental to the value of

3 residential properties. Furthermore, several studies have been conducted to understand the

4 underlying reasons for these inconsistencies.

6 Researchers have used various tools and techniques to explain these inconsistent findings. Most

7 authors have incorporated spatial data into developed models. In other cases, buildings have

8 been classified based on characteristics, such as ownership. For instance, previous studies have

9 shown that the proximity of train stations to properties in low-income neighbourhoods increases

10 their values, however, it has a negative impact in high-income areas (Nelson, 1992; Forouhar

11 \& Hasankhani, 2018; Zhang et al., 2021). Using geospatial data, Bowes and Ihlanfeldt (2001)

12 showed that properties located within 0.25 miles of the MARTA (Metropolitan Atlanta Rapid

13 Transit Authority) sold for 19 per cent less than outside of the three-mile radius. The existing

14 literature on this subject is summarised and presented in Appendix 1. Based on the evidence,

15 scholars have attributed the observed inconsistencies to various reasons.

17 The factors suggested by scholars include the level of car ownership, noise population, and 18 perceived level of security, among others. Forouhar and Hasankhani (2018) observed that train 19 services tend to be utilised as the main means of transportation among low-income families. 20 However, high-income earners can afford to own cars and pay for other associated costs, such 21 as maintenance costs. Others (such as Bowes \& Ihlanfeldt, 2001) stated that the presence of rail 22 stations improves access to a locality. However, the perceived level of security and noise 23 pollution tends to adversely affect the value of residential properties. From Appendix 1, it is 24 evident that most of the studies have focused on single-family homes in the US. Hence, there is a need to understand the impact of railway stations on the value of residential properties in 
1 other cities outside of the US.

\section{$7 \quad$ Residential Property Values: Modelling and Prediction}

8 Various tools have been used to model the relationship between the value of residential 9 properties and their attributes. Research shows that these attributes contribute to the value of 10 properties (Jenkins, 2000). according to Chen et al. (1998), these attributes were classified 11 into structural, neighbourhood, locational, fiscal or economic attributes. In contrast, 12 Mohammad et al. (2013) categorised these attributes into internal, external, and economic 13 (see Figure 1). The nomenclature of the property attributes classifications has not been 14 consistent in the literature (Chin \& Chau, 2002). Taken together, the literature suggests that 15 the attributes of properties have a significant impact on their value. Unearthing the 16 relationship between attributes and property value is vital for optimising the returns on 17 investment.

24 There is a growing number of research that models and predicts residential property values using its attributes. Information gleaned from the literature indicates that the features 26 influencing property values include the number of bedrooms, bathrooms, parking space, 27 proximity of green parks, and academic performance of students in state schools, among 28 others (Crompton, 2001; Abidoye \& Chan, 2017; Fleishman et al., 2017). Table 1 provides a 
1 concise overview of the variables incorporated into models for the prediction of property

2 value. Lines of evidence have shown that these features are useful for modelling and 3 predicting residential property values (Nguyen \& Cripps, 2001; Abidoye, 2017). The impact 4 of these attributes tends to vary from one location to another. Hence, the need to understand 5 the critical attributes that contribute to property values in each location.

6

7

8

9 10 11 12 13 14 15 16 17

\section{Insert Table 1 Here}

\section{University Impact on Residential Property Values}

The presence of UNSW within the study area necessitates the review of studies on the effect of education facilities on the value of residential properties. Much of the research has focused on the impact of school quality, measured in terms of students' academic performance, on the value of properties. For instance, studies have shown that school quality has a positive impact on residential property values (Chin \& Foong, 2006; Wen et al., 2014). However, little is known about the effect of school proximity on property values. Hence, there is a need to understand the impact of the presence of a university on the value of residential properties, using UNSW as a representative case.

Numerous studies have attempted to explain the impact of different levels of schools on the value of residential properties. For instance, Owusu-Edusei et al. (2007) found that elementary and high schools had a great impact on the values of residential 
1 properties in South Carolina, US. Similarly, studies have reported that the presence of

2 school is a significant contributory factor to the values of residential properties in

3 South Korea, China, and the United Kingdom (Davidoff \& Leigh, 2008; Hahn et al., 4 2012; Wen et al., 2014). Wen et al. (2014) showed that the strength of this relationship

5 varies based on the class of the school, e.g. kindergarten schools, high schools, or 6 college. Collectively, it is evident that the proximity and accessibility of all schools 7 have a positive effect on the value of residential properties. These studies highlight 8 the place of educational facilities on property value formation.

10 RESEARCH METHODOLOGY 11

12 Several techniques have been used for modelling and predicting residential property 13 values. The methods used in previous studies can be classified into two groups: 14 quantitative and qualitative. The main advantage of quantitative methods lies in the 15 possibility of objectively verifying and validating the developed model. Despite the 16 existence of several quantitative methods (see Appendix 1), the suitability of a 17 particular approach is dependent on the objectives of the study. In this study, the HPM 18 is used to model and explain the strength of the relationship between the value of a 19 residential property and its attributes. HPM utilises the regression analysis to 20 deconstruct the value of a residential building and estimates the contributory 21 significance of each available characteristic (Selim, 2009). Yacim and Boshoff (2014) 22 point out that the main weakness of HPM is the non-inclusion of the spatial 23 information about residential properties. A better approach would be the inclusion of 24 a dummy variable, which represents the distance between a property and the railway 25 station, in the HPM. Geographic Information System (GIS) is a useful tool for 26 evaluating the impact of distance on the value of real estate properties (Anselin, 1998). 
1 For this study, the dummy variables were included in the HPM model to evaluate the

2 impact of distance to a railway station on property value.

3 The variables included in the quantitative models, i.e. HPM, were informed by the

4 outcome of an initial review of the literature. As stated earlier, dummy variables were

5 used to investigate the impact of the proximity of light rail stops on residential property

6 values. In this research, HPM was applied to data collected from two time periods (

7 (i) the announcement of the new train line and (ii) the completion of the new train

8 station). The variables included in the developed HPM are shown in Table 2.

9 The HPM developed in this study can be specified as a multiple regression as shown in

10 Equation 1.

$$
\begin{array}{r}
P R I C E=\beta_{0}+\beta_{1} \times B D R M+\beta_{2} \times B T H R+\beta_{3} \times P R K G+\beta_{4} \times A G E \\
+\beta_{5} \times A R E A+\beta_{6} \times L O T S Z+\beta_{7} \times P T Y P E+\beta_{8} \times D 400+\beta_{9} \times D 800+\varepsilon
\end{array}
$$

Where $\beta_{0}$ is the regression constant, $\beta_{1} \ldots B_{9}$ are the regression coefficients (described and listed in Table 2) and $\varepsilon$ is the random error.

\section{Study Area}

24 The new CSELR in Sydney, Australia comprises the L2 (Randwick Line) and the L3 25 (Kingsford Line). The CSELR is 12 kilometres and it has 19 stops. The development 26 phase of the CSELR project spanned between December 2012 and March 2020. The 27 government of New South Wales declared and announced the intention to procure the 
1 project in December 2012. Planning permission was granted in 2014. Subsequently,

2 the construction phase commenced in March 2015 and the project was completed in

3 early 2020. The Randwick Line was opened and operational on December 14, 2019,

4 while the Kingsford Line continued testing through the first quarter of 2020 and

5 opened for passengers on April 3, 2020.

6 Two light rail stations served the UNSW community - one via L2 on High Street and

7 one via L3 on Anzac Parade. The impact of these two stops on the value of residential

8 properties is the main focus of the current study. The residential properties were

9 grouped into two classes, i.e. those within the $0-400 \mathrm{~m}$ radius and those located within

10 the $401-800 \mathrm{~m}$ radius. This is a common metric used in similar previous studies (see,

11 for instance, Weinberger, 2001; Hess \& Almeida, 2007; Pan, 2013). Also, Zhong and

$12 \mathrm{Li}$ (2016) mentioned that some residents are willing to walk about $800 \mathrm{~m}$ to a transit stop in America. Figure 2 shows the location of the two rail stations in proximity to the UNSW's Kensington campus.

15

16

\section{Data Collection}

Insert Figure 2 Here

The secondary data used for the study was retrieved from CoreLogic's RP database (https://www.corelogic.com.au/). The descriptive statistics for the variables included 27 in the HPMs are presented in Table 3 (' $\mathrm{N}$ ' indicates the number of observations per model). The selection criteria for the variables are (i) the outcome of the literature review (Table 1) and (ii) the availability of data on the RP database. Upon completion 30 of data cleaning, a total of $702(286+416)$ complete observations were available for 
1 the development of the quantitative models. The data was collected for residential

2 properties sold and bought within the study area between December 2012 and March

32020 when the new rail line was completed. To have consistent property values

4 consummated between 2012 and 2020, the effect of inflation was considered.

5 Therefore, the Consumer Price Index (CPI) retrieved from the Australian Bureau of

6 Statistics (ABS) was applied to the data. The dataset was divided into the light rail

7 announcement (T1) and construction (T2) phases. The post-construction phase was

8 not considered in the study due to the outbreak of the COVID-19 pandemic. This is

9 because global events, such as recession and pandemics, tend to disrupt the housing

10 markets (Lai et al., 2006). This disruption informed the authors' decision not to include

11 post-construction data into the developed HPM. The descriptive statistics and HPM

12 were then generated using the Statistical Package for the Social Sciences (SPSS).

13 Table 3 presents the descriptive statistics showing an increasing value in the average

14 sales price of residential properties when the T1 and T2 periods are compared.

Insert Table 3 Here

20 Results and Discussion

21 The output of the developed models is summarised in Table 4. Lin and Mohan (2011)

22 posit that an $r^{2}$ value closer to 1 demonstrates higher confidence of correlation between

23 the dependent and independent variables. The models for T1 and T2 have $r^{2}$ values of

24.808 and .867 , and adjusted $r^{2}$ values of 0.801 and .864 , respectively. This metric 
1 indicates that the models can explain over 80 per cent variance $(80.8 \%$ for $\mathrm{T} 1$ and

$286.7 \%$ for T2) in the values of residential properties. From these values, both models

3 demonstrate the goodness-of-fit of the HPM (Abidoye, 2017).

4

5

6

7

8

9

10

11

12

13 Tables 5 and 6 presents the regression results of the two models during the 14

Insert Table 4 Here

announcement and construction phase, respectively. The results provide insight into whether each independent variable is significant in contributing to property values during those periods. A p-value of less than .05 means the variable is significant at the 5 per cent significance level and less than .01 means highly significant at the 1 per cent significance level. The collinearity statistics column provides information on whether multicollinearity is present among the variables. To test for multicollinearity, as a general rule of thumb, a variance inflation factor (VIF) value of less than 10 is considered acceptable (Berenson et al., 2012). The values of VIF shown in Tables 5 and 6 are less than 10. Hence, it is evident that there is no multicollinearity among the variables included in the models.

Insert Table 5 Here 


\section{Insert Table 6 Here}

\section{Property Characteristics}

14 The characteristics of the properties (size of the property, number of bedrooms, 15 number of parking spaces, and property type) are significant and have a positive 16 correlation to the value of the residential properties. This finding is consistent with 17 those of previous studies which indicate that structural variables are the most 18 significant drivers of property values (Wilhelmsson, 2000; Abidoye \& Chan, 2016; 19 Chen et al., 2019). This may be because structural attributes of properties are usually 20 significant in the formation of property values (Wilhelmsson, 2000), and they could 21 contribute above 60 per cent to the formation of residential property values (Wen et 22 al., 2005).

23 The number of bathrooms was found to be significant during T1 but not significant in

24 T2. In T2 the number of bathrooms had a negative correlation to property value and 25 for every increase in the number of bathrooms, there is a 1.7 per cent decrease in 26 property value. The plausible reason might be that the home buyers were more 27 concerned about other variables than the number of bathrooms during this period to 28 secure properties close to the light rail stops. This result is similar to the findings of 29 Abidoye and Chan (2018) and Nguyen and Cripps (2001) that reported that an 30 additional number of bathrooms could reduce the price of residential properties. 
1 Property type was found to be highly significant in both T1 and T2. The positive

2 correlation indicates that the average value of standalone houses is higher than those

3 of flats/units. After all other variables are accounted for, the values of properties are

4 predicted to be 49 per cent more than the value of units in T1 and 65 per cent more in

5 T2. This corroborates Mulley and Tsai (2016) that found that units were valued lesser

6 than houses within the same property market. This result could be explained by the

7 fact that houses provide more space, privacy, and amenities when compared with units.

8 These additional features make houses command a higher value.

9

10 In model $\mathrm{T} 1$, the age of property is not significant, but in $\mathrm{T} 2$, the age of property is

11 significant at the 5 per cent significance level. One reason age is not significant in $\mathrm{T} 1$

12 could be that particular architectural styles of properties, such as federation style, may

13 appreciate due to historical value. On the other hand, it has been established in the

14 literature that the older a property, the lesser the value (Hui et al., 2007), and this

15 explains the negative correlation in $\mathrm{T} 2$.

16 The results for both the D400 and D800 are not significant during T1. The positive

17 coefficients of those variables can be interpreted as properties in the two zones that

18 enjoy value-added due to proximity to the stops. Properties located within the $0-400$

19 m range of the stops are predicted to sell for 4.3 per cent premium, while those in the

20 401-800 $\mathrm{m}$ range sold at about 1 per cent premium. This suggests that during the 21 announcement phase, properties located in direct proximity to the planned stops did 22 not experience a negative influence on their values. This outcome is contrary to 23 previous studies (such as Chen et al., 1998; Bowes \& Ihlanfeldt, 2001; Pan, 2013) who 24 found that the railway stations had a negative effect on properties adjacent to the train 25 stations. This outcome may be because T1 is before the construction and operation of 
1 the LRT so negative externalities were not yet present. Also, residential properties

2 located within the $0-400 \mathrm{~m}$ radius of the two stops are close to the UNSW. The

3 proximity to the university could explain the high value attached to properties located

4 within the $0-400 \mathrm{~m}$ radius. Previous studies have shown that the ease to access school

5 facilities tends to have a positive influence on residential property values (Clark \&

6 Herrin, 2000; Chin \& Foong, 2006). On the other hand, this result contradicts the findings

7 of Yan et al. (2012) who reported that the positive influence is only experienced during

8 the operation of light rails. However, there may be other explanatory variables for the

9 negative impact e.g. the presence of surrounding industrial land use.

10

11

12

13

14

In $\mathrm{T} 2$, the D400 variable was highly significant at 1 per cent significance level and D800 was not significant at 1 and 5 per cent significance levels. Both variables are again positively associated as they were in T1. Properties within $0-400 \mathrm{~m}$ of the stops are expected to sell with a 6.7 per cent premium, while those within $401-800 \mathrm{~m}$ were expected to sell with a 3.6 per cent premium. This finding shows that properties closer to the light rail stops were valued higher than those located outside the $0-400 \mathrm{~m}$ radius. Since both $\mathrm{T} 1$ and $\mathrm{T} 2$ produced results that indicate higher property values closer to the LRT stops, this could mean properties directly adjacent to the stops were not affected by negative externalities. One possible reason for this could be linked to the fact that LRT technology does not produce noticeable negative externalities. The CSELR is powered by electricity and it produces less air pollution when compared with fossil powered variants. However, the overhead cables of the CSELR may affect the aesthetical views in the city. The results also suggest that the capitalisation effect of being located closer to UNSW may cancel out the negative externalities or is actually greater than that of the new transit system altogether. 


\section{Development Timeline}

2 By comparing the results of $\mathrm{T} 1$ and $\mathrm{T} 2$, the development timeline of $\mathrm{T} 2$ appears to have a

3 higher positive effect on residential property values. This is evident as both the

4 minimum and maximum sale price of properties in T2 are higher than that of T1. Most

5 of the variables also saw an increase in their coefficient from T1 to T2. With regards

6 to distance, the coefficient for properties located within $0-400 \mathrm{~m}$ of the stops saw an

7 increase of 2.4 per cent in their values, while and properties within 400-800m saw an

8 increase of 2.6 per cent in value. This can be interpreted as the impact of CSELR on

9 property values improved from the announcement phase to the construction phase.

10 The observed increase in value during the development timeline is in line with 11 previous studies such as Yan et al. (2012), Chen et al. (2019) among others. There is 12 a possibility that the values of residential properties would still increase when the new 13 rail line becomes operational because would-be homeowners may not be willing to 14 invest early as benefits of the transit system such as accessibility and travel cost 15 savings cannot be actualised until the system is operational.

17 Proximity and timing are the variables of interest in this study. In terms of timing of 18 value uplift, T2 outperformed T1. From the lens of proximity, it is evident that 19 accessibility to rail stations led to increased property values. Overall, residential 20 property values increased with proximity to LRT stops and did not appear to be 21 affected by negative externalities. Residential property values were also positively 22 affected during the announcement and construction phase but were only statistically 23 significant during the construction phase.

\section{Conclusions}

26 The impact of LRT accessibility on the value of residential properties has been 
1 inconclusive in the existing literature. This present study aimed to address this gap in

2 knowledge by examining the effect of a new light rail system on residential property

3 values around UNSW in Sydney, Australia. Also, the effect of the rail system during

4 the development timeline was evaluated. Using HPM, the study was able to address

5 the objectives of the research. The results of this investigation have shown that

6 residential property values increased during the announcement and construction phase

7 of the railway project. Also, it was found that residential properties located within the

$8 \quad 0-400 \mathrm{~m}$ radius attract more value when compared with properties far away from the

9 railway stops.

10 The current study provides insights into the impact of railway stations on the value of 11 residential properties. Overall, evidence indicates that the proximity to railway stations 12 contributes to an increase in the value of residential properties. Apart from providing 13 jobs to the people, it is evident that new transport infrastructure, such as the LRT 14 system, can add value to the community. Based on the evidence of value uplift, 15 policymakers need to develop policies to optimise the capture of the value of 16 investments in infrastructure projects. Also, stakeholders, such as real estate 17 professionals and property investors, can use this information to objective inform 18 property investment decisions.

19 The findings emanating from the study are subject to certain limitations. First, the 20 variables included in the HPM model was not exhaustive. For instance, there was no 21 information on green features, such as gardens, within the database. Second, the 22 general state of the economy after the completion of the CSELR was not considered. 23 Due to the outbreak of COVID-19, the data for the post-construction phase is not 24 currently available. Despite these limitations, the study contributes to the existing 25 knowledge on the impact of transport infrastructure on the value of residential 
1 properties. As more data become available, further research could explore the impact

2 of CSELR on the value of properties at the post-construction phase.

\section{References}

5

6

7

8

9

10

11

12

13

14

15

16

17

18

19

20

21

22

23

24

25

26

27

28

29

30

31

32

33

34

35

36

37

38

39

40

41

42

43

44

45

46

Abidoye, R. B. (2017). Towards property valuation accuracy: A comparison of hedonic pricing model and artificial neural network. (Doctorate Degree), The Hong Kong Polytechnic University, Hong Kong. Retrieved from http://ira.lib.polyu.edu.hk/bitstream/10397/70359/2/991021965755503411 pir a.pdf (LG51.H577P BRE 2017 Abidoye)

Abidoye, R. B., \& Chan, A. P. (2018). Hedonic valuation of real estate properties in Nigeria. Journal of African Real Estate Research, 3(1), 122-140.

Abidoye, R. B., \& Chan, A. P. C. (2016). Critical determinants of residential property value: Professionals' perspective. Journal of Facilities Management, 14(3), 283-300.

Abidoye, R. B., \& Chan, A. P. C. (2017). Critical review of hedonic pricing model application in property price appraisal: A case of Nigeria. International Journal of Sustainable Built Environment, 6(1), $250 \quad-259$. doi:10.1016/j.ijsbe.2017.02.007

Anselin, L. (1998). GIS research infrastructure for spatial analysis of real estate markets. Journal of Housing Research, 9(1), 113-133.

Berenson, M., Levine, D., Szabat, K. A., \& Krehbiel, T. C. (2012). Basic business statistics: Concepts and applications. Australia: Pearson Higher Education AU.

Bowes, D. R., \& Ihlanfeldt, K. R. (2001). Identifying the impacts of rail transit stations on residential property values. Journal of urban Economics, 50(1), 1-25.

Camins-Esakov, J., \& Vandegrift, D. (2018). Impact of a light rail extension on residential property values. Research in Transportation Economics, 67, 11-18.

Chen, H., Rufolo, A., \& Dueker, K. J. (1998). Measuring the impact of light rail systems on single-family home values: A hedonic approach with geographic information system application. Transportation Research Record, 1617(1), 38-43.

Chen, Y., Yazdani, M., Mojtahedi, M., \& Newton, S. (2019). The impact on neighbourhood residential property valuations of a newly proposed public transport project: The Sydney Northwest Metro case study. Transportation Research Interdisciplinary Perspectives, 3, 100070.

Chin, H. C., \& Foong, K. W. (2006). Influence of school accessibility on housing values. Journal of urban planning and development, 132(3), 120-129.

Chin, T. L., \& Chau, K. W. (2002). A critical review of literature on the hedonic price model. International Journal for Housing Science and its Applications, 27(2), 145-165.

Clark, D. E., \& Herrin, W. E. (2000). The impact of public school attributes on home sale prices in California. Growth and Change, 31(3), 385-407.

Crompton, J. L. (2001). The impact of parks on property values: A review of the empirical evidence. Journal of leisure research, 33(1), 1-31.

Davidoff, I., \& Leigh, A. (2008). How much do public schools really cost? Estimating the relationship between house prices and school quality. Economic Record, 84(265), 193-206. 
Debrezion, G., Pels, E., \& Rietveld, P. (2007). The impact of railway stations on residential and commercial property value: A meta-analysis. The Journal of Real Estate Finance and Economics, 35(2), 161-180.

Duncan, M. (2008). Comparing rail transit capitalization benefits for single-family and condominium units in San Diego, California. Transportation Research Record, 2067(1), 120-130.

Fleishman, L., Fogel, N., Fridman, I., \& Shif, Y. (2017). The effect of school performance on property values: a literature review and a case study. Journal of European Real Estate Research, 10(3), 277-302.

Forouhar, A., \& Hasankhani, M. (2018). The effect of Tehran metro rail system on residential property values: A comparative analysis between high-income and low-income neighbourhoods. Urban studies, 55(16), 3503-3524.

Hahn, S., Kim, T.-H., \& Kim, M. (2012). The influence of school quality on housing prices in Korea. Applied Economics, 44(8), 1021-1023.

Hess, D. B., \& Almeida, T. M. (2007). Impact of proximity to light rail rapid transit on station-area property values in Buffalo, New York. Urban studies, 44(5-6), 1041-1068.

Hui, E. C., Chau, C., Pun, L., \& Law, M. (2007). Measuring the neighboring and environmental effects on residential property value: Using spatial weighting matrix. Building and Environment, 42(6), 2333-2343.

Jenkins, D. (2000). Residential valuation theory and practice. Oxford: Chandos Publishing.

Jorgenson, A. K., \& Clark, B. (2010). Assessing the temporal stability of the population/environment relationship in comparative perspective: A crossnational panel study of carbon dioxide emissions, 1960-2005. Population and Environment, 32(1), 27-41.

$\mathrm{Li}$, Z. (2018). The impact of metro accessibility on residential property values: An empirical analysis. Research in Transportation Economics, 70, 52-56.

Lin, C. C., \& Mohan, S. B. (2011). Effectiveness comparison of the residential property mass appraisal methodologies in the USA. International Journal of Housing Markets and Analysis, 4(3), 224-243.

Mohammad, S. I., Graham, D. J., Melo, P. C., \& Anderson, R. J. (2013). A metaanalysis of the impact of rail projects on land and property values. Transportation Research Part A: Policy and Practice, 50, 158-170.

Mulley, C., \& Tsai, C.-H. P. (2016). When and how much does new transport infrastructure add to property values? Evidence from the bus rapid transit system in Sydney, Australia. Transport Policy, 51, 15-23.

Nelson, A. C. (1992). Effects of elevated heavy-rail transit stations on house prices with respect to neighborhood income. Transportation Research Record(1359), 127-132.

Nguyen, N., \& Cripps, A. (2001). Predicting housing value: A comparison of multiple regression analysis and artificial neural networks. Journal of Real Estate Research, 22(3), 313-336.

Owusu-Edusei, K., Espey, M., \& Lin, H. (2007). Does close count? School proximity, school quality, and residential property values. Journal of Agricultural and Applied Economics, 39(1), 211-221.

Pan, Q. (2013). The impacts of an urban light rail system on residential property values: A case study of the Houston METRORail transit line. Transportation Planning and Technology, 36(2), 145-169.

Pan, Q. (2019). The impacts of light rail on residential property values in a non-zoning 
city: A new test on the Houston METRORail transit line. Journal of Transport and Land Use, 12(1), 241-264.

Pan, Q., Pan, H., Zhang, M., \& Zhong, B. (2014). Effects of rail transit on residential property values: Comparison study on the rail transit lines in Houston, Texas, and Shanghai, China. Transportation Research Record, 2453(1), 118-127.

Ryan, S. (1999). Property values and transportation facilities: Finding the transportation-land use connection. Journal of planning literature, 13(4), 412427.

Selim, H. (2009). Determinants of house prices in Turkey: Hedonic regression versus artificial neural network. Expert Systems with Applications, 36(2), 2843-2852.

Shi, A. (2003). The impact of population pressure on global carbon dioxide emissions, 1975-1996: Evidence from pooled cross-country data. Ecological economics, 44(1), 29-42.

Steffen, W., Percival, T., \& Flannery, D. (2015). Greenhouse gas emission reductions from Canberra's light rail project. Australian Planner, 52(4), 337-345.

Wagner, G. A., Komarek, T., \& Martin, J. (2017). Is the light rail "Tide" lifting property values? Evidence from Hampton Roads, VA. Regional Science and Urban Economics, 65, 25-37.

Weinberger, R. R. (2001). Light rail proximity: Benefit or detriment in the case of Santa Clara County, California? Transportation Research Record, 1747(1), 104-113.

Wen, H.-Z., Jia, S.-H., \& Guo, X.-Y. (2005). Hedonic price analysis of urban housing: An empirical research on Hangzhou, China. Journal of Zhejiang University Science, 6A(8), 907-914.

Wen, H., Zhang, Y., \& Zhang, L. (2014). Do educational facilities affect housing price? An empirical study in Hangzhou, China. Habitat International, 42, 155-163.

Wilhelmsson, M. (2000). The impact of traffic noise on the values of single-family houses. Journal of Environmental Planning and Management, 43(6), 799-815.

Yacim, J. A., \& Boshoff, D. G. (2014, 15-19 December). Mass appraisal of properties. Paper presented at the 2nd Virtual Multidisciplinary Conference, Zilina, Slovakia.

Yan, S., Delmelle, E., \& Duncan, M. (2012). The impact of a new light rail system on single-family property values in Charlotte, North Carolina. Journal of Transport and Land Use, 5(2), 60-67.

Zhang, B., Li, W., Lownes, N., \& Zhang, C. (2021). Estimating the impacts of proximity to public transportation on residential property values: An empirical analysis for Hartford and Stamford areas, Connecticut. ISPRS International Journal of GeoInformation, 10(2), 44. doi:https://doi.org/10.3390/ijgi10020044

Zheng, J., Sun, X., Jia, L., \& Zhou, Y. (2020). Electric passenger vehicles sales and carbon dioxide emission reduction potential in China's leading markets. Journal of Cleaner Production, 243, 118607.

Zheng, X., Wu, Y., Jiang, J., Zhang, S., Liu, H., Song, S., et al. (2015). Characteristics of on-road diesel vehicles: Black carbon emissions in Chinese cities based on portable emissions measurement. Environmental science \& technology, 49(22), 13492-13500.

Zhong, H., \& Li, W. (2016). Rail transit investment and property values: An old tale retold. Transport Policy, 51, 33-48. 